\title{
Aqueous-phase catalytic process for production of pentane from furfural over nickel-based catalysts
}

\author{
Zhang Xinghua $^{\mathrm{a}, \mathrm{b}}$, Wang Tiejun ${ }^{\mathrm{a}, *}$, Ma Longlong ${ }^{\mathrm{a}}$, Wu Chuangzhi ${ }^{\mathrm{a}}$ \\ a Key Laboratory of Renewable Energy and Gas Hydrate, Guangzhou Institute of Energy Conversion, Chinese Academy of Sciences, Guangzhou, Guangdong 510640, PR China \\ ${ }^{\mathrm{b}}$ Graduate School of Chinese Academy of Science, Beijing 100049, PR China
}

\section{A R T I C L E I N F O}

\section{Article history:}

Received 9 December 2009

Received in revised form 12 May 2010

Accepted 31 May 2010

Available online 10 June 2010

\section{Keywords:}

Biomass

Furfural

$\mathrm{Ni}$

Bifunctional catalyst

Pentane

\begin{abstract}
A B S T R A C T
Supported nickel catalysts for aqueous-phase catalytic hydrogenation/dehydration of furfural were prepared using impregnation method with different supporting materials. Effects of supporting materials, nickel loading and reaction temperature on conversion rate of furfural as well as selectivity for desired product $\mathrm{C}_{5}$ were systematically studied. Experiments showed that catalytic activity of $\mathrm{Ni} / \mathrm{SiO}_{2}-\mathrm{Al}_{2} \mathrm{O}_{3}$ was obviously higher than that of $\mathrm{Ni} / \gamma-\mathrm{Al}_{2} \mathrm{O}_{3}$. The conversion of furfural over $14 \mathrm{wt} \% \mathrm{Ni} / \mathrm{SiO}_{2}-\mathrm{Al}_{2} \mathrm{O}_{3} \mathrm{cat}-$ alyst was $62.99 \%$ under the temperature of $140{ }^{\circ} \mathrm{C}$ and the cold pressure of $\mathrm{H}_{2} 3.0 \mathrm{MPa}$, while that was $19.19 \%$ over $14 \mathrm{wt} . \% \mathrm{Ni} / \gamma-\mathrm{Al}_{2} \mathrm{O}_{3}$ under the same conditions. Conversion rate of furfural increased with temperature, but selectivity for desired product decreased with temperature. Tentative reaction mechanisms of hydrogenation/dehydration were proposed. In order to investigate catalyst recyclability, a batch of $\mathrm{Ni} / \mathrm{SiO}_{2}-\mathrm{Al}_{2} \mathrm{O}_{3}$ was reused three times and analyzed by Thermogravimetry (TG). It was found that considerable amount of coke formed on $\mathrm{Ni} / \mathrm{SiO}_{2}-\mathrm{Al}_{2} \mathrm{O}_{3}$ surface and deteriorated its activity dramatically after second use.
\end{abstract}

(c) 2010 Elsevier Ltd. All rights reserved.

\section{Introduction}

Biomass offers a sustainable resource for the future. It has the potential advantages in alleviating environmental pollution, slowing global warming, and reducing our dependence on the limited fossil fuels [1]. Especially in recent years, with the increasing price of oil, it is necessary to develop some feasible processes to produce liquid fuels from non-petroleum resources. One of the dramatic strategies for replacing petroleum fuels in the transportation sector is developing biomass-derived liquid fuels, which utilizes the existing delivery infrastructure while no extensive vehicle engine modification is needed [2]. Recently, Dumesic proposed a new scheme to produce alkanes from biomass-derived carbohydrates by aqueous-phase reforming reaction, which could be used as clean diesel fuel for transportation applications [3-5]. Because the process can be accomplished in a single reaction vessel and the products can be separated spontaneously from water, aqueous-reforming of renewable carbohydrates is attractive.

Furan compounds such as furfural, methyl furfural and hydroxymethylfurfural (HMF) can be produced with good yields though catalyzed dehydration of xylose and fructose over solid acid catalysts, mineral or ionic liquid catalysts [6-8]. Especially, furfural can be extracted directly from a variety of agricultural byproducts,

\footnotetext{
* Corresponding author. Fax: +86 2087057737.

E-mail address: wangtj@ms.giec.ac.cn (W. Tiejun).
}

including corncobs, oat and wheat bran, sawdust, and rice husk [9-11], and bio-oil derived from fast pyrolysis of biomass [12]. Thus, the source of furfural is very extensive. Currently, furfural was used for the production of furfural resin and fine chemicals. It can be selectively hydrogenated to form furfuryl alcohol, 2-methylfuran or tetrahydro-2-furancarboxaldehyde [13,14] since furfural is a carbonyl compound containing unsaturated $\mathrm{C}=\mathrm{C}$ bond and $\mathrm{C}=\mathrm{O}$ bond. Furfural can also form longer carbon chain compounds by aldol condensation with ketone, which plays a key role in the production of higher alkanes $\left(\mathrm{C}_{8}-\mathrm{C}_{15}\right)$ from biomass-derived carbohydrates such as xylose and fructose $[2,4,15]$. Currently, pentane could be used as pentane oil, or "bio-gasoline" when being added directly to fossil gasoline due to the similarity of its properties with gasoline. Thus, converting furfural to pentane through combination of hydrogenation and dehydration reactions would be a novel and meaningful approach.

Recently, Dumesic and his co-workers published a series of papers about production of alkanes from biomass-derived carbohydrates in aqueous-phase $[2-5,16]$. The hydrogenation catalysts used in these processes were supported noble metal catalysts, such as $\mathrm{Pt} / \mathrm{SiO}_{2}-\mathrm{Al}_{2} \mathrm{O}_{3}$ and $\mathrm{Pd} / \mathrm{MgO}-\mathrm{ZrO}_{2}[2,5]$. Crocker and co-workers reported that the liquid phase upgrading of a model bio-oil containing 4 wt.\% furfural was investigated over a series of supported Pt catalysts [17]. These catalysts exhibited high catalytic activity and relatively suitable selectivity for production of alkanes. Wellknown to us, nickel is an important catalyst for hydrogenation 
and dehydrogenation, and its catalytic performance is comparable to noble metal catalyst $[18,19]$. Given low cost, mild reaction conditions and excellent catalytic activity of Ni-based catalyst, we loaded $\mathrm{Ni}$ on the commercial supports, such as $\gamma-\mathrm{Al}_{2} \mathrm{O}_{3}$ or $\mathrm{SiO}_{2-}$ $\mathrm{Al}_{2} \mathrm{O}_{3}$, and applied it to aqueous-phase catalytic hydrogenation/ dehydration for alkanes production from furfural. It is desirable to use furfural for initial screening, while leaving the investigation of other biomass-derived carbohydrates and optimization of catalysts the subject of further research.

The main purpose of this study is to develop an approach of converting furfural to pentane over the inexpensive Ni-based bifunctional catalysts in water, which consists of repeated "onepot" hydrogenation/dehydration reactions. The focus is on the effects of supporting material, reaction temperature, and nickel loading on conversion rate of furfural and selectivity for desired product.

\section{Experimental section}

\subsection{Catalyst preparation}

$\mathrm{Ni} / \gamma-\mathrm{Al}_{2} \mathrm{O}_{3}$ catalysts were prepared by wet impregnating different amounts of $\gamma-\mathrm{Al}_{2} \mathrm{O}_{3}$ with $\mathrm{Ni}\left(\mathrm{NO}_{3}\right)_{2} \cdot 6 \mathrm{H}_{2} \mathrm{O}$ aqueous solutions. The solutions were evaporated and the residues were dried at $120{ }^{\circ} \mathrm{C}$ then calcined at $450{ }^{\circ} \mathrm{C}$ in the air. The catalysts contained $6,10,14$ and $17 \mathrm{wt} . \% \mathrm{Ni}$, respectively. In the same way, the $\mathrm{Ni} / \mathrm{SiO}_{2}-\mathrm{Al}_{2} \mathrm{O}_{3}$ catalysts were prepared, which also contained 6 , 10, 14 and $17 \mathrm{wt} . \% \mathrm{Ni}$, respectively. Supporting materials $\mathrm{SiO}_{2}-\mathrm{Al}_{2} \mathrm{O}_{3}$ and $\gamma-\mathrm{Al}_{2} \mathrm{O}_{3}$ were commercial products, purchased from TRICI Science and Technology Development Corp. (Tianjin, China). $\mathrm{Al}_{2} \mathrm{O}_{3}$ content is $25 \mathrm{wt} . \%$ in the supporting material $\mathrm{SiO}_{2}-\mathrm{Al}_{2} \mathrm{O}_{3}$. Catalysts were reduced at $450{ }^{\circ} \mathrm{C}$ before use.

\subsection{Experimental equipment and method}

All the aqueous-phase catalytic reactions of furfural were carried out in a $100 \mathrm{ml}$ stainless autoclave equipped with an electromagnetic driven stirrer. The schematic diagram is shown in Fig. 1. For each run, $2.0 \mathrm{~g}$ catalyst, $40 \mathrm{ml}$ water and $2.0 \mathrm{ml}$ furfural were loaded in the autoclave. After displacing air, the $\mathrm{H}_{2}$ pressure was raised to $3.0 \mathrm{MPa}$. The reaction temperature varied from $110^{\circ} \mathrm{C}$ to $220^{\circ} \mathrm{C}$, reagents were vigorously stirred $(800 \mathrm{rpm})$ in order to eliminate the limitation of diffusion. The cumulate gas efflux was measured when desired reaction temperature was achieved. Tail gas samples were collected in vacuum plastic bags for subsequent off-line gas chromatography (GC) analysis.

\subsection{Product analysis and catalyst characterization}

Product were analyzed by GC (Shimadzu GC2010 with a flame ionization detector (FID) and a DB-5 column, $30 \mathrm{~m} \times$ $0.25 \mathrm{~mm} \times 0.1 \mu \mathrm{m}, \mathrm{N}_{2}$ as carrier gas), with alkanes $\left(\mathrm{C}_{1}-\mathrm{C}_{6}\right)$ as the internal standard to confirm their components. The vaporization temperature was $58^{\circ} \mathrm{C}$, the detector temperature was $200{ }^{\circ} \mathrm{C}$, and the oven temperature program ranged from $50{ }^{\circ} \mathrm{C}$ to $70^{\circ} \mathrm{C}$ at the rate of $2{ }^{\circ} \mathrm{C} / \mathrm{min}$.

The BET surface area, External Surface Area, Average Pore Diameter and pore volume of catalysts were determined by $\mathrm{N}_{2}$ isothermal (77 K) adsorption using Micrometrics ASAP-2010 automated system.

$\mathrm{NH}_{3}$ temperature-programmed desorption ( $\mathrm{NH}_{3}$-TPD) studies were carried out in a quartz tube reactor with a thermal conductivity detector (TCD). Catalyst $(100 \mathrm{mg})$ was pretreated in a flow of helium ( $30 \mathrm{ml} / \mathrm{min}$ ) at $400{ }^{\circ} \mathrm{C}$ for $1 \mathrm{~h}$ to remove undesirable physisorbed species, and after cooling to $100{ }^{\circ} \mathrm{C}$, ammonia adsorption was carried out. Physically adsorbed ammonia was removed by purging with helium at $100^{\circ} \mathrm{C}$ for $2 \mathrm{~h}$ before the $\mathrm{NH}_{3}$-TPD. All $\mathrm{NH}_{3}$-TPD profiles were carried out by increasing the temperature from 100 to $600{ }^{\circ} \mathrm{C}$ with a rate of $10^{\circ} \mathrm{C} / \mathrm{min}$ and a helium flow rate of $30 \mathrm{ml} / \mathrm{min}$.

$\mathrm{H}_{2}$ temperature-programmed reduction $\left(\mathrm{H}_{2}\right.$-TPR) studies were carried out in a quartz tube reactor. Fifty milligrams of catalyst was pretreated in a flow of helium $(30 \mathrm{ml} / \mathrm{min})$ at $400{ }^{\circ} \mathrm{C}$ for $1 \mathrm{~h}$ to remove undesirable physisorbed species, and after cooling to $100{ }^{\circ} \mathrm{C}$, the sample was heated in a flow of $5 \% \mathrm{H}_{2} / 95 \% \mathrm{~N}_{2}(30 \mathrm{ml} /$ min) from 100 to $800^{\circ} \mathrm{C}$ at a heating rate of $10^{\circ} \mathrm{C} / \mathrm{min}$. Hydrogen consumption was monitored by the change of thermal conductivity of the effluent gas stream.

TG studies of used catalysts were carried out under an air flow rate of $30 \mathrm{ml} / \mathrm{min}$ with analyzers by using $10-15 \mathrm{mg}$ sample and a $10^{\circ} \mathrm{C} /$ min temperature increasing.

\section{Results and discussion}

The mass balance of carbon estimated by sum of alkane products and unreacted furfural vs. fed furfural are about $90-96 \%$.

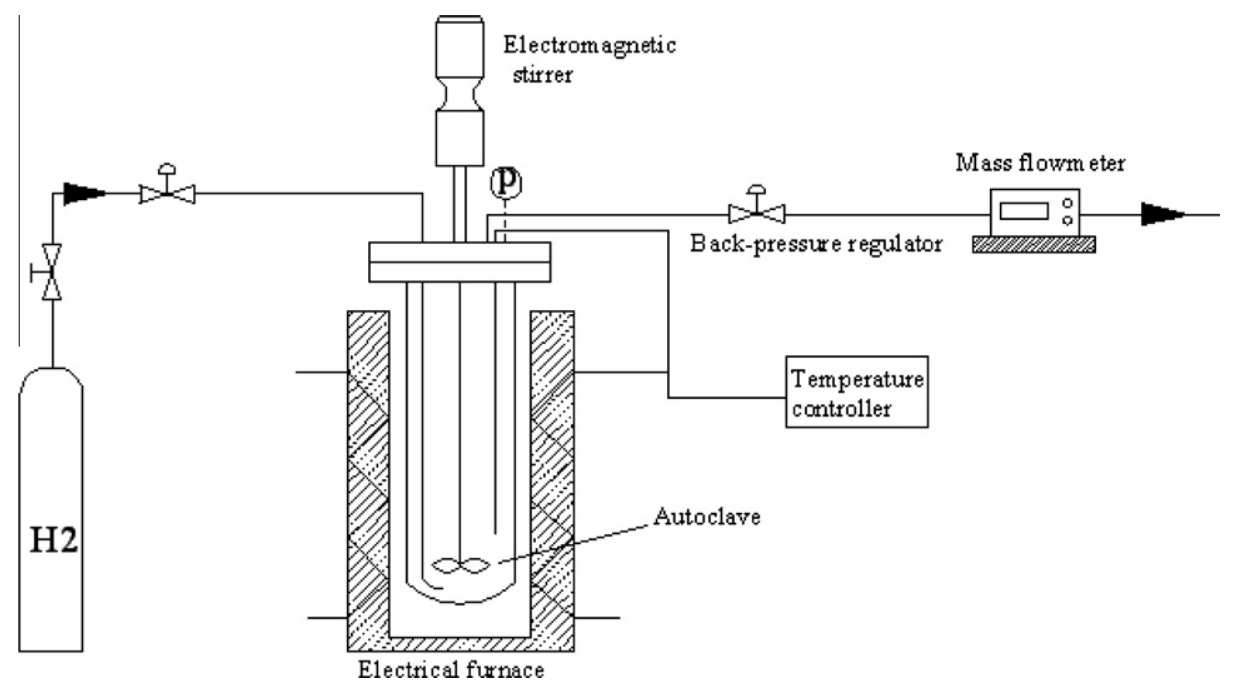

Fig. 1. Schematic diagram of experimental apparatus. 
Table 1

Conversion of furfural over different catalyst $\left(140^{\circ} \mathrm{C}, 3.0 \mathrm{MPa}\right)$.

\begin{tabular}{llc}
\hline Entry & Catalysts & Conversion/\% \\
\hline 1 & $6 w t . \% \mathrm{Ni} / \mathrm{SiO}_{2}-\mathrm{Al}_{2} \mathrm{O}_{3}$ & 12.49 \\
2 & $10 \mathrm{wt} \% \mathrm{Ni} / \mathrm{SiO}_{2}-\mathrm{Al}_{2} \mathrm{O}_{3}$ & 46.17 \\
3 & $14 \mathrm{wt} \% \mathrm{Ni} / \mathrm{SiO}_{2}-\mathrm{Al}_{2} \mathrm{O}_{3}$ & 62.99 \\
4 & $17 \mathrm{wt} . \% \mathrm{Ni} / \mathrm{SiO}_{2}-\mathrm{Al}_{2} \mathrm{O}_{3}$ & 36.28 \\
5 & $6 \mathrm{wt} \% \mathrm{Ni} / \gamma-\mathrm{Al}_{2} \mathrm{O}_{3}$ & 6.41 \\
6 & $10 w \mathrm{wt} \% \mathrm{Ni} / \gamma-\mathrm{Al}_{2} \mathrm{O}_{3}$ & 24.72 \\
7 & $14 \mathrm{wt} \% \mathrm{Ni} / \gamma-\mathrm{Al}_{2} \mathrm{O}_{3}$ & 19.19 \\
8 & $17 w t . \% \mathrm{Ni} / \gamma-\mathrm{Al}_{2} \mathrm{O}_{3}$ & 3.62 \\
\hline
\end{tabular}

The mass loss is ascribed to the formation of polymers or/and cokes during the processes of reaction. Main products of aqueous-phase catalytic hydrogenation/dehydration of furfural are $\mathrm{C}_{1}-\mathrm{C}_{6}$ alkanes, and $\mathrm{C}_{5}$ alkane is the desired product. For the convenience of subsequent discussion, conversions of furfural and product selectivity are calculated based on $C_{5}$ (five carbon atoms per furfural molecule), as shown in the definition formulas listed below [2]:

$$
\begin{aligned}
& \text { Conversion } \%=\frac{\sum_{i=1}^{6} i \times \text { moles } C_{i}}{5 \times \text { moles furfuralfed }_{1}} \times 100 \\
& C_{i} \text { selectivity } \%=\frac{M_{i} \times \text { moles } C_{i}}{\sum_{i=1}^{6} M_{i} \times \text { moles }_{i}} \times 100
\end{aligned}
$$

In the formulas, $i$ is the carbon atom numbers for alkane; $C_{i}$ is the alkane which carbon atom numbers is $i$, and $M_{i}$ is its molar mass.

\subsection{Aqueous-phase catalytic reaction of furfural}

Conversions for aqueous-phase catalytic hydrogenation/dehydration reaction of furfural over different catalysts at $140{ }^{\circ} \mathrm{C}$ are listed in Table 1 . The experimental results indicate that the activity of $\mathrm{Ni} / \mathrm{SiO}_{2}-\mathrm{Al}_{2} \mathrm{O}_{3}$ catalysts is obviously higher than that of $\mathrm{Ni} /$ $\gamma-\mathrm{Al}_{2} \mathrm{O}_{3}$ catalysts under the same reaction conditions. In order to find out the root cause of this difference, characterization of the porous structure was carried out, as summarized in Table 2. From Table 2, it could be concluded that there are two possible reasons. First, the BET surface area of $\mathrm{Ni} / \mathrm{SiO}_{2}-\mathrm{Al}_{2} \mathrm{O}_{3}$ is obviously larger than that of $\gamma-\mathrm{Al}_{2} \mathrm{O}_{3}$. Second, the pore diameter of $\mathrm{SiO}_{2}-\mathrm{Al}_{2} \mathrm{O}_{3}$ is bigger than that of $\gamma-\mathrm{Al}_{2} \mathrm{O}_{3}$. Larger BET surface and bigger pore diameter facilitate the diffusion of reactants and reaction products, hence more complete reactions and higher conversion.

$\mathrm{H}_{2}$-TPR experiment was also carried out in order to explain the difference between catalytic activity of $\mathrm{Ni} / \mathrm{SiO}_{2}-\mathrm{Al}_{2} \mathrm{O}_{3}$ catalysts and $\mathrm{Ni} / \gamma-\mathrm{Al}_{2} \mathrm{O}_{3}$ catalysts from another point of view. The $\mathrm{H}_{2}$-TPR pro-

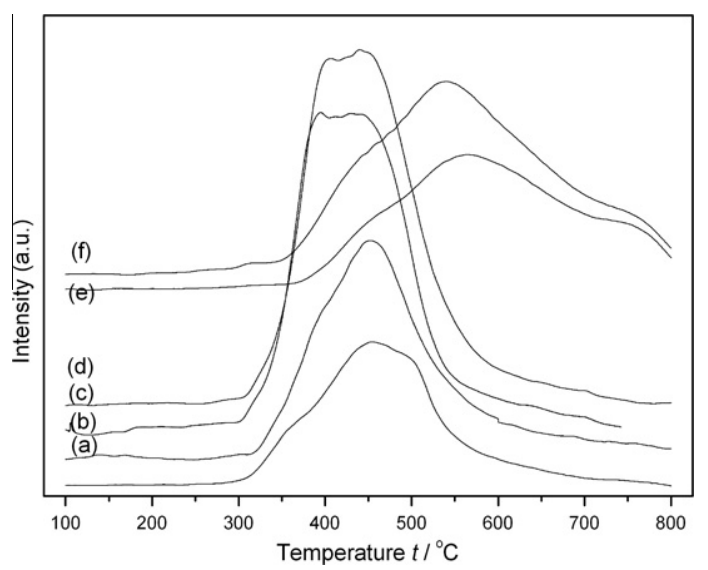

Fig. 2. TPR profiles of $\mathrm{Ni} / \mathrm{SiO}_{2}-\mathrm{Al}_{2} \mathrm{O}_{3}$ and $\mathrm{Ni} / \gamma-\mathrm{Al}_{2} \mathrm{O}_{3}$ catalysts (a) $6 \mathrm{wt} . \% \mathrm{Ni} / \mathrm{SiO}_{2}-\mathrm{Al}_{2} \mathrm{O}_{3}$, (b) $10 \mathrm{wt} . \% \mathrm{Ni} / \mathrm{SiO}_{2}-\mathrm{Al}_{2} \mathrm{O}_{3}$, (c) $14 \mathrm{wt} . \% \mathrm{Ni} / \mathrm{SiO}_{2}-\mathrm{Al}_{2} \mathrm{O}_{3}$, (d) $17 \mathrm{wt} . \% \mathrm{Ni} / \mathrm{SiO}_{2}-\mathrm{Al}_{2} \mathrm{O}_{3}$, (e) $10 \mathrm{wt} . \% \mathrm{Ni} / \gamma-\mathrm{Al}_{2} \mathrm{O}_{3}$, and (f) $14 \mathrm{wt} . \% \mathrm{Ni} / \gamma-\mathrm{Al}_{2} \mathrm{O}_{3}$.

files of catalysts are presented in Fig. 2. All profiles in Fig. 2 show a two-stage reduction behavior. A low temperature reduction peaks centered at about $370{ }^{\circ} \mathrm{C}$ is observed for $\mathrm{Ni} / \mathrm{SiO}_{2}-\mathrm{Al}_{2} \mathrm{O}_{3}$ catalysts owing to the reduction of dispersed $\mathrm{NiO}$ that does not interact with support material. A reduction peak centered at about $450{ }^{\circ} \mathrm{C}$ is common for all the profiles owing to the reduction of $\mathrm{NiO}$ weakly interacted with support material; and a high temperature reduction peak centered at about $580{ }^{\circ} \mathrm{C}$ is observed for $\mathrm{Ni} / \gamma-\mathrm{Al}_{2} \mathrm{O}_{3}$ catalysts owing to the formation of amorphous $\mathrm{Ni}$ aluminates. It is suggested that $\mathrm{Ni} / \gamma-\mathrm{Al}_{2} \mathrm{O}_{3}$ catalysts should be reduced at higher temperatures. However, these catalysts used in aqueous-phase catalytic hydrogenation/dehydration of furfural were all reduced at $450{ }^{\circ} \mathrm{C}$, hence the reduction degree of $\mathrm{Ni} / \gamma-\mathrm{Al}_{2} \mathrm{O}_{3}$ catalysts would be low and result in lower catalytic activity.

It can also be seen from Table 1 that conversion increases with loading of $\mathrm{Ni}$ on the $\mathrm{SiO}_{2}-\mathrm{Al}_{2} \mathrm{O}_{3}$. A maximum is observed over $14 \mathrm{wt} . \% \mathrm{Ni} / \mathrm{SiO}_{2}-\mathrm{Al}_{2} \mathrm{O}_{3}$ catalyst. Beyond this loading amount, a significant decrease of conversion takes place, which can be attributed to the increase of $\mathrm{Ni}$ loading giving rise to aggregation of $\mathrm{Ni}$ particles, thereby leading to the decline of catalyst activity. This aggregation of metal nickel is accompanied by a lower External Surface Area and Ni dispersion of catalysts which can be seen in Table 2. Similar phenomenon recurred with $\mathrm{Ni} / \gamma-\mathrm{Al}_{2} \mathrm{O}_{3}$ catalysts. The difference was that the conversion of furfural had reached the maximum while the loading of $\mathrm{Ni}$ was $10 \mathrm{wt} . \%$ on $\gamma-\mathrm{Al}_{2} \mathrm{O}_{3}$.

Fig. 3(A) and (B) shows the distribution of products derived from aqueous-phase catalytic hydrogenation of furfural over dif-

Table 2

\begin{tabular}{|c|c|c|c|c|c|}
\hline & $A_{\mathrm{BET}}\left(\mathrm{m}^{2} / \mathrm{g}\right)$ & $A_{\text {ext }}\left(\mathrm{m}^{2} / \mathrm{g}\right)$ & $V^{\mathrm{a}}\left(\mathrm{cm}^{3} / \mathrm{g}\right)$ & $D^{\mathrm{b}}(\AA)$ & Ni dispersion ${ }^{\mathrm{c}}(\%)$ \\
\hline $\mathrm{SiO}_{2}-\mathrm{Al}_{2} \mathrm{O}_{3}$ & 278.7 & 269.1 & 1.53 & 219.9 & - \\
\hline 6 wt. $\% \mathrm{Ni} / \mathrm{SiO}_{2}-\mathrm{Al}_{2} \mathrm{O}_{3}$ & 215.86 & 209.13 & 0.94 & 168.2 & 4.12 \\
\hline 10 wt. $\% \mathrm{Ni} / \mathrm{SiO}_{2}-\mathrm{Al}_{2} \mathrm{O}_{3}$ & 208.76 & 206.33 & 0.89 & 170.5 & 2.77 \\
\hline 14 wt.\%Ni $/ \mathrm{SiO}_{2}-\mathrm{Al}_{2} \mathrm{O}_{3}$ & 197.33 & 213.59 & 0.82 & 166.0 & 2.36 \\
\hline 17 wt. $\% \mathrm{Ni} / \mathrm{SiO}_{2}-\mathrm{Al}_{2} \mathrm{O}_{3}$ & 196.31 & 172.34 & 0.77 & 156.5 & 1.06 \\
\hline$\gamma-\mathrm{Al}_{2} \mathrm{O}_{3}$ & 193.3 & 183.7 & 0.84 & 154.1 & - \\
\hline 6 wt.\%Ni $/ \gamma-\mathrm{Al}_{2} \mathrm{O}_{3}$ & 145.71 & 143.27 & 0.39 & 107.1 & 3.32 \\
\hline 10 wt. $\% \mathrm{Ni} / \gamma-\mathrm{Al}_{2} \mathrm{O}_{33}$ & 145.9 & 139.8 & 0.29 & 79.5 & 2.54 \\
\hline 14 wt. $\% \mathrm{Ni} / \gamma-\mathrm{Al}_{2} \mathrm{O}_{3}$ & 139.00 & 136.59 & 0.27 & 79.1 & 1.86 \\
\hline 17 wt.\%Ni $/ \gamma-\mathrm{Al}_{2} \mathrm{O}_{3}$ & 135.8 & 110.23 & 0.20 & 58.9 & 0.98 \\
\hline
\end{tabular}

Porous structure characterization of the different catalysts.

$A_{\mathrm{BET}}$ : BET surface area.

$A_{\text {ext }}$ : External Surface Area.

${ }^{a} \mathrm{~V}$ : BJH adsorption cumulative pore volume of pores between 17.0 and $3000.0 \mathrm{~A}$ diameter.

b $D$ : Adsorption Average Pore Diameter.

c Determined by $\mathrm{H}_{2}$ chemisorption. 

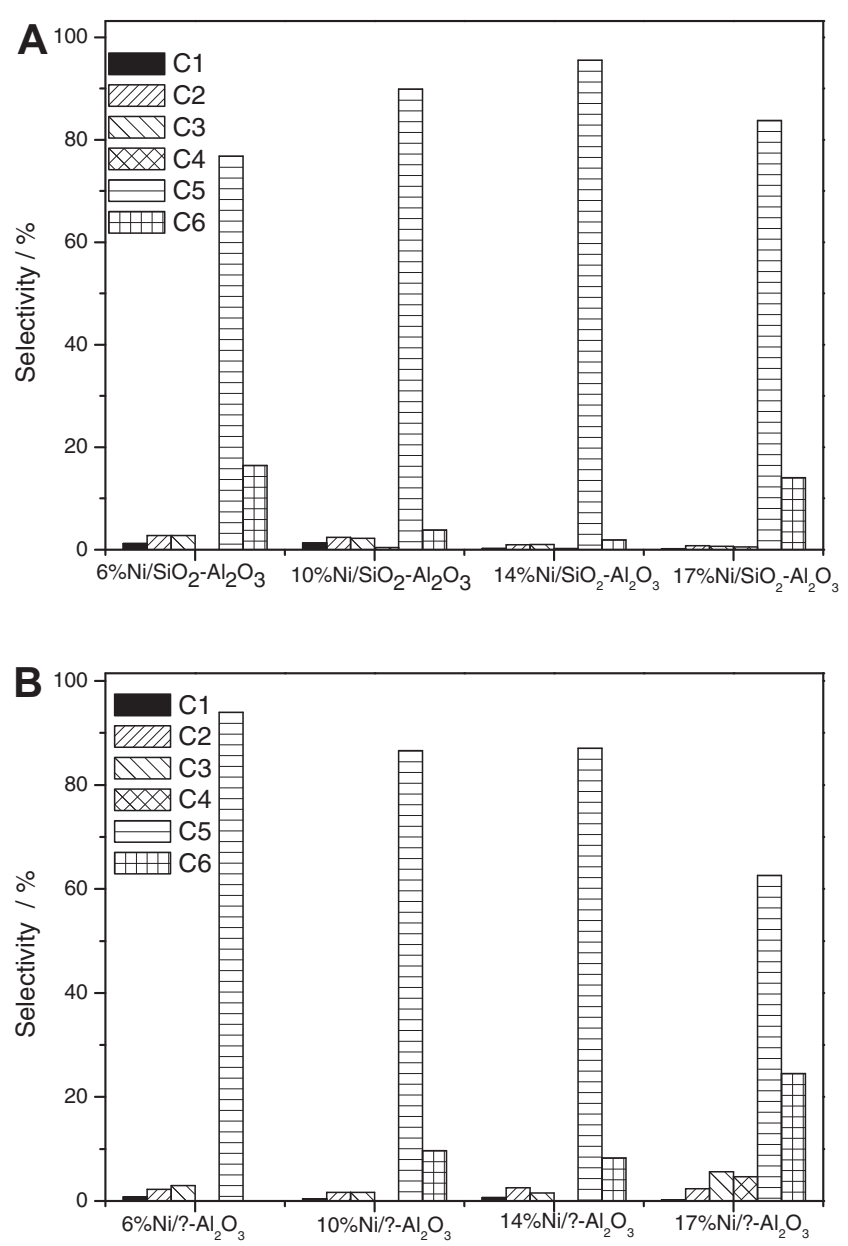

Fig. 3. Product selectivity at $140{ }^{\circ} \mathrm{C}$ over different catalysts.

ferent catalysts. It can be seen that the catalysts $\mathrm{Ni} / \mathrm{SiO}_{2}-\mathrm{Al}_{2} \mathrm{O}_{3}$ and $\mathrm{Ni} / \gamma-\mathrm{Al}_{2} \mathrm{O}_{3}$ exhibit relatively high selectivity for the desired $\mathrm{C}_{5}$ alkanes. Ni loadings of catalysts have some effects on the selectivity. The Fig. 3(A) indicates that the content of desired $C_{5}$ products increases gradually from $76.8 \%$ to $95.5 \%$ while the Ni loadings of catalysts $\mathrm{Ni} / \mathrm{SiO}_{2}-\mathrm{Al}_{2} \mathrm{O}_{3}$ increases from 6 to $14 \mathrm{wt}$.\%. However, the selectivity for $\mathrm{C}_{5}$ decreases slightly when $\mathrm{Ni}$ loading further increases to $17 \mathrm{wt} . \%$. On the contrary, Fig. 3(B) shows that $6 \mathrm{wt} . \% \mathrm{Ni} / \gamma-\mathrm{Al}_{2} \mathrm{O}_{3}$ catalyst exhibits the highest selectivity and the selectivity decreases gradually with the increase of $\mathrm{Ni}$ loading. The selectivity decreases to only $62.6 \%$ while Ni loading increases to $17 \mathrm{wt} . \%$.

To explain the effects of Ni loadings on the selectivity for the desired product, External Surface Area and Adsorption Average Pore Diameter of $\mathrm{Ni} / \mathrm{SiO}_{2}-\mathrm{Al}_{2} \mathrm{O}_{3}$ catalysts with different $\mathrm{Ni}$ loadings are compared. External Surface Area and the Adsorption Average Pore Diameter of catalysts are almost constant, which means that the acid sites provided by $\mathrm{SiO}_{2}-\mathrm{Al}_{2} \mathrm{O}_{3}$ were not covered by the increasing loading $\mathrm{Ni}$ in the loading range from 6 to 14 wt.\% while the quantity of active Ni particles increased with $\mathrm{Ni}$ loading. Thus, the metal-catalyzed (Ni-catalyzed) hydrogenation and solid acid-catalyzed dehydration co-worked well together, and improved product selectivity. As shown in Table 2, External Surface Area and Adsorption Average Pore Diameter of $\mathrm{Ni} / \mathrm{SiO}_{2}-\mathrm{Al}_{2} \mathrm{O}_{3}$ catalyst decrease significantly when the $\mathrm{Ni}$ loading further increases to $17 \mathrm{wt} . \%$. It means that the acid sites reduced because they were covered by $\mathrm{Ni}$ particles, so solid acid-catalyzed dehydration was hindered and could not co-work

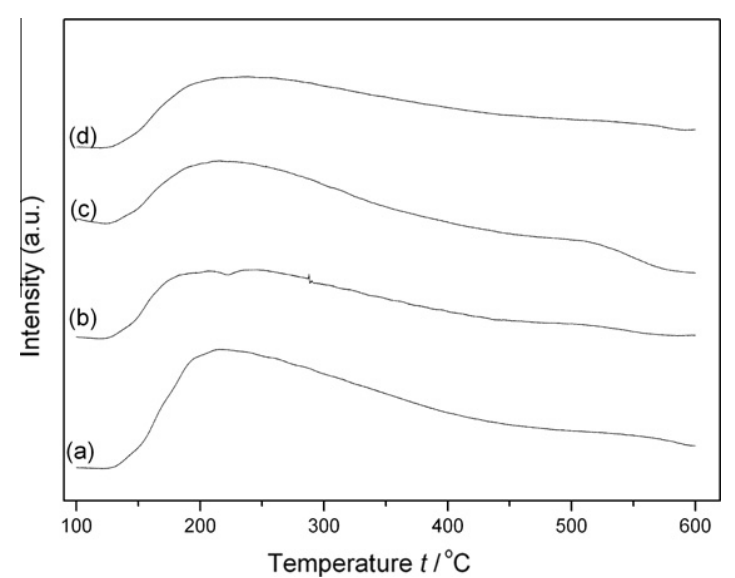

Fig. 4. $\mathrm{NH}_{3}$-TPD profiles of $\mathrm{Ni} / \mathrm{SiO}_{2}-\mathrm{Al}_{2} \mathrm{O}_{3}$ catalysts (a) $6 \mathrm{wt} . \% \mathrm{Ni} / \mathrm{SiO}_{2}-\mathrm{Al}_{2} \mathrm{O}_{3}$, (b) 10 wt. $\% \mathrm{Ni} / \mathrm{SiO}_{2}-\mathrm{Al}_{2} \mathrm{O}_{3}$, (c) 14 wt. $\% \mathrm{Ni} / \mathrm{SiO}_{2}-\mathrm{Al}_{2} \mathrm{O}_{3}$, and (d) $17 \mathrm{wt} . \% \mathrm{Ni} / \mathrm{SiO}_{2}-\mathrm{Al}_{2} \mathrm{O}_{3}$.

well with metal-catalyzed hydrogenation, leading to selectivity decrease.

To afford additional supports to the results obtained from External Surface Area and Adsorption Average Pore Diameter of $\mathrm{Ni} / \mathrm{SiO}_{2}-$ $\mathrm{Al}_{2} \mathrm{O}_{3}$ catalysts with different $\mathrm{Ni}$ loadings discussed above, $\mathrm{NH}_{3}-\mathrm{TPD}$ experiments were carried out to characterize the acid amounts of various catalysts. The overall acid amounts in various catalysts can be inferred from the relative peak areas of the $\mathrm{NH}_{3}$ desorption curves. The $\mathrm{NH}_{3}-\mathrm{TPD}$ profiles for various $\mathrm{Ni} / \mathrm{SiO}_{2}-\mathrm{Al}_{2} \mathrm{O}_{3}$ catalysts are shown in Fig. 4, it is found that the overall acid amounts decreased gradually with increasing Ni loading. It could be concluded that the metal-catalyzed hydrogenation and acid-catalyzed dehydration could not co-work well because the overall acid amounts of catalyst decrease to a small value when Ni loading increases to $17 \mathrm{wt} . \%$, leading to the product selectivity for $C_{5}$ decrease. These results agree with those obtained from External Surface Area and Adsorption Average Pore Diameter of $\mathrm{Ni} / \mathrm{SiO}_{2}-\mathrm{Al}_{2} \mathrm{O}_{3}$ catalysts.

\subsection{Effects of reaction temperature}

Conversion and product selectivity of aqueous-phase catalytic hydrogenation/dehydration of furfural at different reaction temperatures were illustrated in Figs. 5 and 6, respectively. These results show that reaction temperature has a pronounced effect on conversion and product selectivity of furfural. In the investigated temperature range, the conversion of furfural increases obviously with reaction temperature, no matter the catalyst is $\mathrm{Ni} / \mathrm{SiO}_{2}-$ $\mathrm{Al}_{2} \mathrm{O}_{3}$ or $\mathrm{Ni} / \gamma-\mathrm{Al}_{2} \mathrm{O}_{3}$. However, byproducts increased swiftly with reaction temperature. The selectivity for desired product $C_{5}$ is the highest at the temperature of $140{ }^{\circ} \mathrm{C}$ from Fig. $6(\mathrm{~A})$ and (B), and other products such as $C_{1}, C_{2}, C_{3}$, and $C_{4}$ are very few. At the temperature of $220^{\circ} \mathrm{C}, \mathrm{C}_{1}$ and $\mathrm{C}_{2}$ are increased obviously, and selectivity for the desired product $C_{5}$ is lower than $60 \%$. Thus, the optimum temperature for hydrogenation/dehydration of furfural is $140{ }^{\circ} \mathrm{C}$, which provides a good balance between conversion and product selectivity of furfural.

\subsection{Aqueous-phase catalytic reaction pathways}

Tentative aqueous-phase catalytic reaction pathways for the production of pentane from furfural under bifunctional Ni-based catalysts are shown in Fig. 7. In this process, various reactions pathways may exist. On the metal $\mathrm{Ni}$ active sites, furfural is hydrogenated to intermediates such as furfuryl alcohol, tetrahydro-2-furancarboxaldehyde, tetrahydrofurfuryl alcohol and 


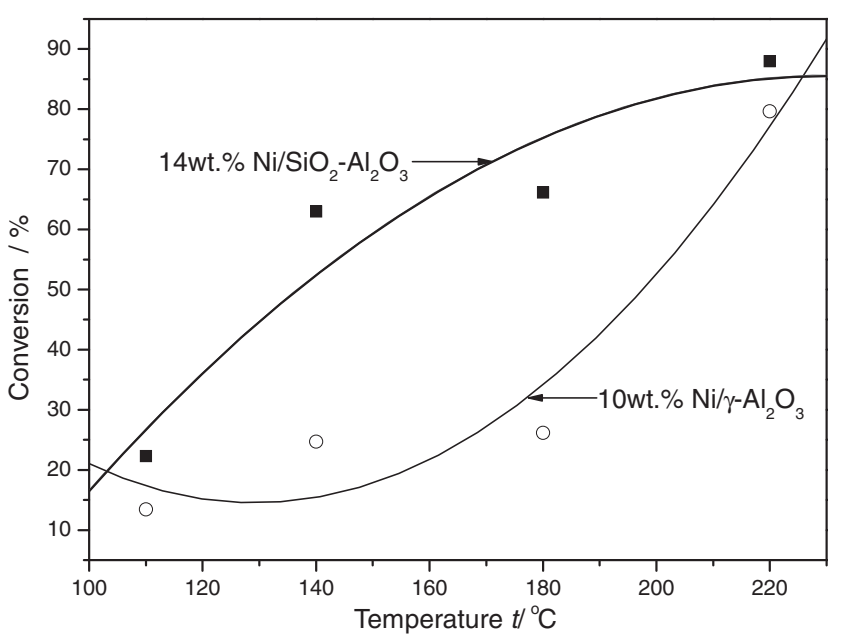

Fig. 5. Conversion of furfural at different temperature (3.0 MPa).
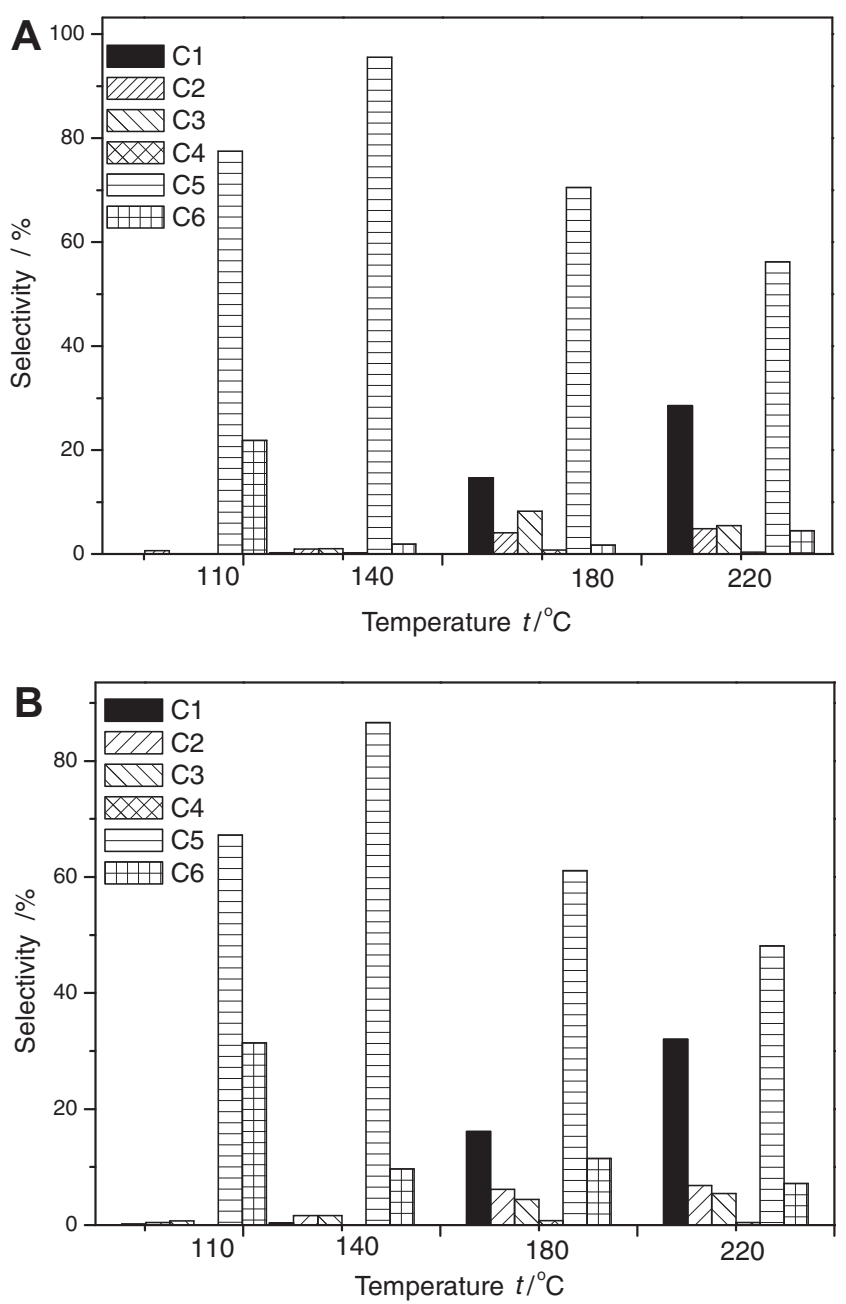

Fig. 6. Selectivity for products at different temperature (3.0 MPa) (A) $14 \mathrm{wt} . \% \mathrm{Ni} /$ $\mathrm{SiO}_{2}-\mathrm{Al}_{2} \mathrm{O}_{3}$ catalyst and (B) $10 \mathrm{wt} . \% \mathrm{Ni} / \gamma-\mathrm{Al}_{2} \mathrm{O}_{3}$ catalyst.

1,5-pentanediol and so on. These intermediates migrate to acid sites of bifunctional catalyst where they undergo dehydration reaction and become alkenes. The subsequent hydrogenation step saturates the $\mathrm{C}=\mathrm{C}$ bonds of alkenes, thereby producing pentane.

Lighter alkanes such as $C_{1}, C_{2}, C_{3}$, and $C_{4}$ were also observed. Production of various lighter alkanes by aqueous-reforming of hydrogenated reaction intermediates of furfural depends on the

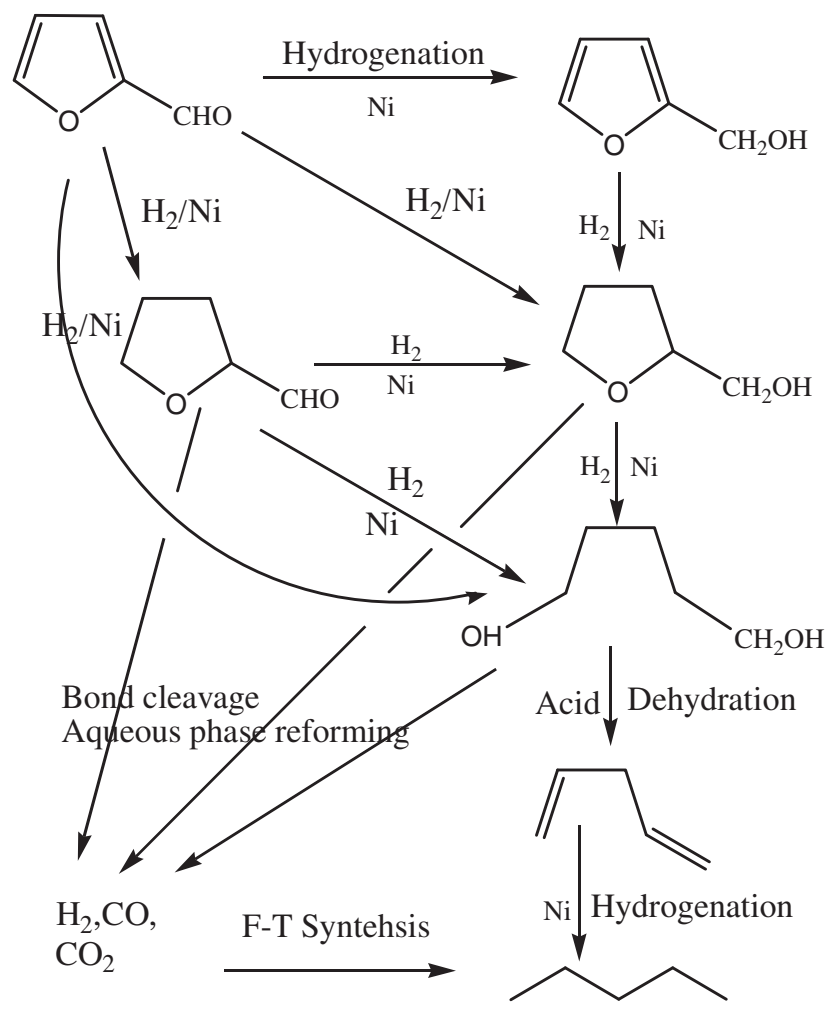

Fig. 7. Reaction pathways for the production of pentane from furfural.

relative rates of $\mathrm{C}-\mathrm{C}$ bond cleavage, dehydration and hydrogenation reactions [5]. In addition, lighter alkane $\mathrm{CH}_{4}$ can also be formed by hydrogenation of $\mathrm{CO}$ and $\mathrm{CO}_{2}$ derived from aqueousreforming of hydrogenated reaction intermediates of furfural on metal $\mathrm{Ni}$ under high pressure of $\mathrm{H}_{2}$ [20]. It should be noted that $\mathrm{C}_{6}$ was also observed in products, although minor. According to the literature, it was formed via Fischer-Tropsch reactions between $\mathrm{H}_{2}$ and the reforming products, $\mathrm{CO}$ or/and $\mathrm{CO}_{2}$ [21].

\subsection{Catalyst recyclability}

To investigate the recyclability of catalyst, a batch of $14 \mathrm{wt} . \% \mathrm{Ni} /$ $\mathrm{SiO}_{2}-\mathrm{Al}_{2} \mathrm{O}_{3}$ was used repeatedly for the aqueous-phase catalytic hydrogenation of furfural at $140{ }^{\circ} \mathrm{C}$ and under cold pressure of $\mathrm{H}_{2}$ 3.0 MPa. As shown in Table 3, a significant drop in conversion of furfural was observed after the catalyst was reused twice. It could be concluded that catalyst had lost its activity after two runs. Catalyst deactivation might be mainly attributed to coke formed during the aqueous-phase catalytic hydrogenation/dehydration of furfural, covering active sites of catalysts. In addition, it should be noticed that polymerization of furfural could also happen under the conditions of aqueous-phase catalytic hydrogenation/dehydration, and the formed polymer might deposit on the surface of catalyst and result in deactivation.

In order to examine the extent of coke formation during the aqueous-phase catalytic hydrogenation of furfural with $14 \mathrm{wt} . \% \mathrm{Ni} /$ $\mathrm{SiO}_{2}-\mathrm{Al}_{2} \mathrm{O}_{3}$ catalyst, Thermogravimetry (TG) method was employed

Table 3

Results of repeated use of $14 \mathrm{wt} . \% \mathrm{Ni} / \mathrm{SiO}_{2}-\mathrm{Al}_{2} \mathrm{O}_{3}$ catalyst.

\begin{tabular}{ll}
\hline Entry & Conversion/\% \\
\hline 1 & 62.99 \\
2 & 57.53 \\
3 & 26.24 \\
\hline
\end{tabular}




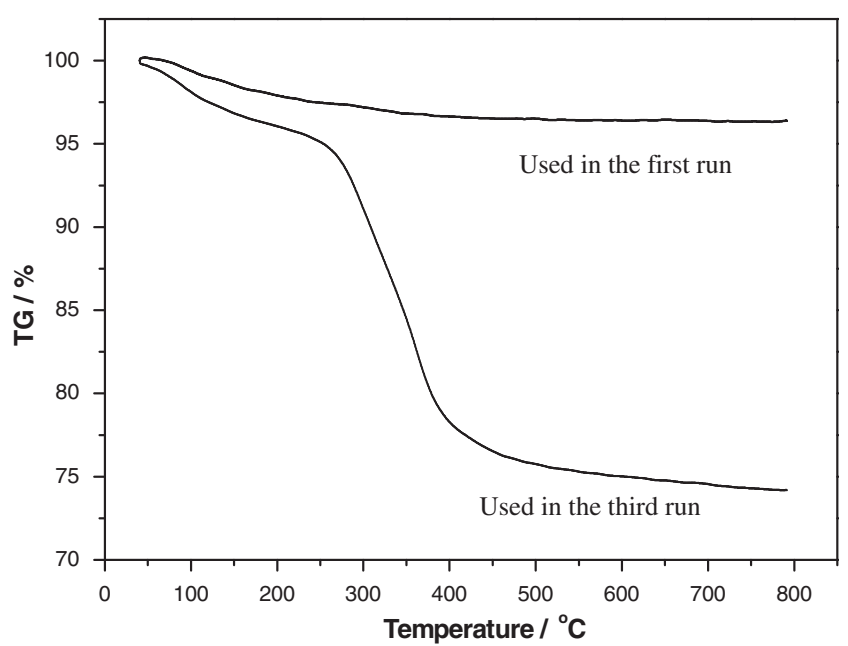

Fig. 8. TG curve of the used 14 wt. $\% \mathrm{Ni} / \mathrm{SiO}_{2}-\mathrm{Al}_{2} \mathrm{O}_{3}$ catalyst.

to analyze the used catalysts. TG curves of catalysts are illustrated in Fig. 8. There is only a slight weight loss for catalyst used once but more than $25 \%$ weight loss for the catalyst used thrice. The weight loss may be attributed to the combustion of residual polymer or/ and coke deposited on catalysts. We speculate that most of activate sites of catalyst have been covered by coke during the first two run, and furfural is prone to polymerization in the absence of activated catalyst during aqueous-phase hydrogenation. Thus, improvements and optimization of catalysts to avoid coke are required in further studies.

\section{Conclusions}

In this paper, a new route for alkane production by the aqueousphase catalytic hydrogenation/dehydration of furfural has been developed. Ni metal in combination with solid acid supports (such as $\mathrm{SiO}_{2}-\mathrm{Al}_{2} \mathrm{O}_{3}, \gamma-\mathrm{Al}_{2} \mathrm{O}_{3}$ ) act as bifunctional catalysts for one-pot hydrogenation/dehydration conversion of furfural in water through coupling metal-catalyzed hydrogenation and solid acidcatalyzed dehydration. The new route provides a feasible approach for alkane production from biomass via furans platform.

\section{Acknowledgements}

This work was supported by grants from the National Natural Science Foundation of China (No. 50776092) and Key Orientation Project Knowledge Innovation Program of Chinese Academy of Science (No. KSCX2-YW-G-063). The authors also thank for the help from Dr. Liu Qiying for the measuration of Ni dispersion.

\section{References}

[1] Wu C, Yin X, Ma L, Zhou Z, Chen H. Design and operation of a 5.5 MWe biomass integrated gasification combined cycle demonstration plant. Energy Fuels 2008;22:4259-64.

[2] Barrett CJ, Chheda JN, Huber GW, Dumesic JA. Single-reactor process for sequential aldol-condensation and hydrogenation of biomass-derived compounds in water. Appl Catal B - Environ 2006;66:111-8.

[3] Huber GW, Cortright RD, Dumesic JA. Renewable alkanes by aqueous-phase reforming of biomass-derived oxygenates. Angew Chem Int Ed 2004; $43: 1549-51$.

[4] Chheda JN, Dumesic JA. An overview of dehydration, aldol-condensation and hydrogenation processes for production of liquid alkanes from biomassderived carbohydrates. Catal Today 2007;123:59-70.

[5] Huber GW, Dumesic JA. An overview of aqueous-phase catalytic processes for production of hydrogen and alkanes in a biorefinery. Catal Today 2006;111:119-32.

[6] Zhao HB, Holladay JE, Brown H, Zhang ZC. Metal chlorides in ionic liquid solvents convert sugars to 5-hydroxymethylfurfural. Science 2007;316:1597-600.

[7] Binder JB, Raines RT. Simple chemical transformation of lignocellulosic biomass into furans for fuels and chemicals. J Am Chem Soc 2009;131:1979-85.

[8] Román-Leshkov Y, Chheda JN, Dumesic JA. Phase modifiers promote efficient production of hydroxymethylfurfural from fructose. Science 2006;312:1933-7.

[9] Lima S, Pillinger M, Valente AA. Dehydration of D-xylose into furfural catalysed by solid acids derived from layered zeolite Nu-6(1). Catal Commun 2008;9:2144-8.

[10] Masaki Sagehashi, Tsuyoshi Nomura, Hiromu Shishido, Akiyoshi Sakoda Separation of phenols and furfural by pervaporation and reverse osmosis membranes from biomass - superheated steam pyrolysis-derived aqueous solution. Bioresour Technol 2007;98:2018-26.

[11] Vázquez M, Oliva M, Téllez-luis SJ, Ramírez J. Hydrolysis of sorghum straw using phosphoric acid: evaluation of furfural production. Bioresour Technol 2007;98:3053-60.

[12] Peng J, Chen P, Lou H, Zheng X. Catalytic upgrading of bio-oil by HZSM-5 in sub- and super-critical ethanol. Bioresour Technol 2009;100:3415-8.

[13] Kijenski J, Winiarek P, Paryjczak T, et al. Platinum deposited on monolayer supports in selective hydrogenation of furfural to furfuryl alcohol. Appl Catal A - Gen 2002;233:171-82.

[14] Wu S, Wei W, Li B, Zhao W, Huang W, Zhang S. Studies on hydrogenation of furfural to 2-methylfuran over $\mathrm{Cu}-\mathrm{Cr} / \gamma-\mathrm{Al}_{2} \mathrm{O}_{3}$ catalyst prepared by different methods. Chin J Catal 2003;24:27-31.

[15] West RM, Liu ZY, Peter M, Gärtner CA, Dumesic JA. Carbon-carbon bond formation for biomass-derived furfurals and ketones by aldol condensation in a biphasic system. J Mol Catal A - Chem 2008;296:18-27.

[16] Chheda JN, Huber GW, Dumesic JA. Liquid-phased catalytic processing-derived oxygenated hydrocarbons to fuels and chemicals. Angew Chem Int Ed 2007;46:7164-83.

[17] Fisk CA, Morgan T, Ji Y, Crocker M, Crofcheck C, Lewis SA. Bio-oil upgrading over platinum catalysts using in situ generated hydrogen. Appl Catal A - Gen 2009;358:150-6.

[18] Lewandowska A, Bettahar M, Ziolek M. MCM-41 mesoporous molecular sieves supported nickel-physico-chemical properties and catalytic activity in hydrogenation of benzene. J Mol Catal A - Chem 2002;188:85-95.

[19] Infantes-Molina A, Mérida-Robles J, Braos-García P, Rodríguez-Castellón E, Finocchio E, Busca G, et al. Nickel supported on porous silica as catalysts for the gas-phase hydrogenation of acetonitrile. J Catal 2004;225:479-88.

[20] Davda RR, Shabaker JW, Huber GW, Cortright D, Dumesic JA. Aqueous-phase reforming of ethylene glycol on silica-supported metal catalysts. Appl Catal B Environ 2003;43:13-26.

[21] Davda RR, Shabaker JW, Huber GW, Cortright D, Dumesic JA. A review of catalytic issues and process conditions for renewable hydrogen and alkanes by aqueous-phase reforming of oxygenated hydrocarbons over supported metal catalysts. Appl Catal B - Environ 2005;56:171-86. 